\title{
Effect of low caloric diet supplemented by fennel (Foeniculum vulgare) seeds or black cumin (Nigella sativa) seeds and its mixture on obese adult female patients
}

\section{Mohamed A. AbdElwahab ${ }^{1}$, Ekbal M. Mohamed ${ }^{1}$ and Eman M. Fahmy2}

1- Department of Home Economics, Division of Nutrition and Food Sciences, Faculty of Specific Education, Ain Shams University, Cairo, Egypt

2- Faculty of Medicine, Helwan University, Cairo, Egypt

Received: April 1, 2021; Accepted: April 21,3021.; Available online: April 30, 2021.

\begin{abstract}
The present work was carried out to study the effect of low caloric diet supplemented with fennel seeds or black cumin seeds and their mixture on obese adult females. The control group (G1) used low caloric diet with $1000 \mathrm{kcal}$ without supplementation, while groups (2 and 3) used low caloric diet supplemented with $5 \mathrm{~g}$ black cumin and $5 \mathrm{~g}$ fennel seeds seeds, respectively. On the other hand, group (4) used low caloric diet supplemented a mixture of $2.5 \mathrm{~g}$ fennel seeds and $2.5 \mathrm{~g}$ black cumin seeds. All supplementation were mixed with a cup of light yoghurt in dinner meal. The study was performed for 4 weeks. Anthropometric measurements and levels of serum triglyceride, cholesterol, LDL and HDL were taken pre and post the study. Females taken low caloric diet supplemented with black cumin (G2) or mixture of black cumin and fennel (G4) recorded significant decrease in their BMI when compared to the control group. Cases supplemented with Fennel (G3) recorded insignificant decrease in their BMI. The total cholesterol decreased significantly in groups (2 and 4), while it was decreased insignificantly in group (3) compared to the control group. HDL levels increased significantly in groups ( $2 \& 4)$ compared to group (1).

Results of the present study indicated that significant decrease were in total body weight, BMI, WC, AC, TSF and AMC in group (2) which received black cumin seeds, followed by group (4) which received mixture of black cumin seeds and fennel seeds, followed by group (3) which received fennel seeds compared to the control group.
\end{abstract}

Keywords: Fennel- Black cumin- low caloric diet- obesity, females.

\section{INTRODUCTION}

Obesity is defined as the condition of excessive fat accumulation to such an extent that affects persons health (Polikandrioti and Stevanou, 2009). It represents one of the major nutritional health problems in different countries of the world and it is a major risk factor for the development of various pathological conditions including insulin resistance, diabetes, cardiovascular diseases, and nonalcoholic fatty liver disease. Also, it is associated with chronic low-grade inflammation in many tissues including adipose, liver, muscle, kidney, pancreas and brain (Heping et al., 2020).
Prescription of low caloric diets by reduction of 500-1000 kcal/day from usual intake will lead to a weight loss of approximately $\quad 0.5-1 \quad \mathrm{~kg} /$ week (Gonzalez-Campoy et al., 2013). Low caloric diets usually begining at 1000$1200 \mathrm{kcal} /$ day, with diets below 1000 $\mathrm{kcal} /$ day sufficient in older, smaller and inactive individuals.

Fennel seeds (Foeniculum vulgare) contain carbohydrates, alkaloids, Phytosterols, phenols, tannins and flavonoids, much of dietary fiber, protein, calcium, iron, magnesium and manganese. Pharmacologically, it possess antioxidant, anti-inflammatory, antispasmodic, diuretic, antihypertensive, antimicrobial, Gastro 
Mohamed A. AbdElwahab et al.

protective, estrogenic, Hepatoprotective and antithrombotic activities (Shahid, 2018). Fennel seeds were used to investigate the possible interaction between a conventional drug used for management of cholesterol and traditional herbal remedies on the obesity (Nawal et al., 2019).

Black cumin (Nigella sativa) and its active component thymoquinone have been shown to have positive effects in controlling glucose levels and lipid profiles in diabetics (Heshmati and Namazi, 2015).

Bariatric surgery for obesity is associated with a greater risk of complications, also medications for obesity causes some of side effects and not recommended for children or adolescents (Kelly et al., 2013), therefore the best treatment methods for obesity are natural methods that depend on diets. It is also possible to support some natural plants to give better results and in a safe manner on public health without side effects.

The aim of the present study is to investigate the effect of low caloric diet supplemented by fennel (Foeniculum vulgare) seeds or black cumin (Nigella sativa) seeds or their mixture on obese adult female patients

\section{MATERIALS AND METHODS}

This study was carried out on a hundred obese adult females from nutrition clinic in Badr Helwan University Hospital. They are free from other concomitant diseases, and their BMI is greater than 30 $\mathrm{kg} / \mathrm{m}^{2}$, age (20-40) years. The period of the study was 4 weeks. The patients were divided into 4 groups as following: Group (1) received low calories diet about 1000 Kcal (Controlgroup). Group (2) received low calories diet plus $5 \mathrm{~g}$ /day black cumin seeds. Group (3) received low calories diet plus $5 \mathrm{~g} /$ day fennel seeds. The fourth group received low calories diet plus $5 \mathrm{~g}$ /day mixture (Fennel $2.5 \mathrm{~g}$ and black cumin $2.5 \mathrm{~g}$ ) seeds.
Fennel and black cumin seeds were purchased from agriculture research center Giza and were blended to be powder.

Anthropometric measurements: These were taken weekly and include height, total body weight - body mass index (BMI) - Waist circumference (WC), Midupper arm circumference and Triceps skinfold thickness.

Height : It was measured to the nearest 0.5 $\mathrm{cm}$ by using a vertical metric rule.

Total body weight: It was measured to the nearest $1 \mathrm{~kg}$ using a balance. Female removed her shoes, heavy clothes and objects before weighing.

Body mass index (BMI): It was calculated according to the following formula:

BMI = Body Weight $(\mathrm{kg}) /$ (height $(\mathrm{m})^{2}$ (Dudek, 2001).

Table (1): Classification of BMI (Nazma et al., 2017).

\begin{tabular}{|l|l|}
\hline Category & BMI $(\mathrm{kg} / \mathrm{m} 2)$ \\
\hline Under weight & $<18.5$ \\
\hline Healthy weight & $18.5-24.9$ \\
\hline Pre obese state & $25.0-29.9$ \\
\hline Obese grade I & $30.0-34.9$ \\
\hline Obese grade II & $35.0-39.9$ \\
\hline Obese grade III & $\geq 40$ \\
\hline
\end{tabular}

WC-mid is a better measurement to define central obesity than WC-IC, particularly in women WC-mid is a better measurement to define central obesity than WC-IC, particularly in women

Waist circumference (WC): WC-mid was measured in the horizontal plane midway between lowest rib and the iliac crest. Both WC-IC and WC-mid were measured to the nearest $0.1 \mathrm{~cm}$ at the end of a normal expiration by using nonstretchable tape measure. Before recording the measurement, the nurse would ensure that the tape was snug but did not 


\section{Effect of low caloric diet supplemented by fennel (Foeniculum vulgare) seeds or black cumin (Nigella sativa) seeds and its mixture on obese adult female patients}

compress the skin and was parallel to the floor. Standard $=80-88 \mathrm{~cm}$ for woman and 94-102 cm for men (Nhlbi, 1998).

Med-upper Arm circumference (MUAC): Objective to assess the use of (MUAC) for identification of overweight, place a nonstretchable tape, preferably an insertion tap for easy reading, at the midpoint of the cases non-dominant arm between the top of the scapula and the olecranon process of the ulna with the forearm flexed at $90^{\circ}$. With the arm in the dependent position, gently and firmly draw the tap around the mid upper arm; do not compress the soft tissue. Record the reading to the nearest centimeters.

$90 \%$ standard $=25.7 \mathrm{~cm}$ for women, $26.3 \mathrm{~cm}$ for men (Dudek, 2001).

Triceps skinfold thickness (TSF): Measured from triceps area by using caliper device, while the case arm was hanging freely, grasp a fold of skin and subcutaneous fat between the thumb and forefinger slightly above the midpoint mark. Gently pull the skin away from the underlying muscle, apply the calipers, wait 2 to 3 seconds, and read the measurements to the nearest $1.0 \mathrm{~mm}$. Repeat the procedure 2 times more; add the three reading, and record their average.

$90 \%$ standard $=11.3 \mathrm{~mm}$ for men, 14.9 $\mathrm{mm}$ for woman (Abd-elkader, 2001; Dudek, 2001).

Arm muscle circumference (AMC): It was calculated from MUAC and TSFT measurements, provides an index of muscle mass. It is calculated in centimeters as following equation:

AMC $(\mathrm{cm})=\operatorname{MUAC}(\mathrm{cm})-(3.14 \times$ TSFT $\mathrm{cm})$ (Abd-elkader, 2001)

$90 \%$ standard $=22.8 \mathrm{~cm}$ in men $\quad, \quad 20.9$ $\mathrm{cm}$ in woman. (Dudek, 2001)

Laboratory analysis: Serum lipids
Triglyceride, total cholesterol, low density lipoprotein (LDL) and High density lipoprotein (HDL) were measured as recommended by Wendy et al. (2005). Hemoglobin level also was measured. All measurements have been taken at the beginning and the end of the study.

Statistical Analysis: These were carried out using ANOVA test.

The low-calorie diet: It was designed around $1000 \mathrm{kcal}$ according to food exchange list of American dietetic association (ADA, 2008).

Nutrition supplementation: Black cumin seeds and fennel seeds were grounded into a powder. Five grams of each of them were added to a cup of light yoghurt (110 $\mathrm{g})$ in the dinner meal. Mixture of fennel seeds $2.5 \mathrm{~g}$ and black cumin seeds $2.5 \mathrm{~g}$ were grounded into a powder and were added to 1 cup of light yoghurt (110 gm) in the dinner meal.

\section{RESULTS AND DISCUSSION}

The results in Table (2) revealed that the mean daily calories intake pre dietary intervention were $(2123 \pm 152$, $2086 \pm 166, \quad 2116 \pm 138 \quad \& \quad 2096 \pm 190$ $\mathrm{k.cal} /$ day) for groups (1, 2, 3 \& 4), respectively. While, the mean daily calories intake post dietary intervention were $1013 \pm 62, \quad 1013 \pm 62, \quad 1036 \pm 54 \quad \&$ $1023 \pm 42 \mathrm{k} . c a l$ /day for groups $(1,2,3 \&$ $4)$, respectively. It was obvious that after dietary intervention for weight loss, calories intake/ day decreased by percentage $(53.3 \%)$ in group (1), followed by $(51.4,52.1 \& 51.4 \%)$ for groups $(2,3$ $\&$ 4) respectively. This decreased approved with (DRIs) recommendation which recommended that less amount of crobydrate, protein and fats intake/day for adult woman (19-50 years old) were (130 , 46 and $30 \mathrm{~g} /$ day, respectively. 
Mohamed A. AbdElwahab et al.

Table (2): Daily calories intake (pre \& post) study for obese adult female patients

\begin{tabular}{|l|c|c|c|c|c|}
\hline $\begin{array}{l}\text { Measuring } \\
\text { parameter }\end{array}$ & Treatment & Group 1 & $\begin{array}{c}\text { Group 2 } \\
\text { (black cumin) }\end{array}$ & $\begin{array}{c}\text { Group 3 } \\
\text { (fennel) }\end{array}$ & $\begin{array}{c}\text { Group 4 } \\
\text { (mix) }\end{array}$ \\
\hline \multirow{2}{*}{$\begin{array}{l}\text { Calories } \\
\text { (k.cal) }\end{array}$} & Pre invention & $2123 \pm 152$ & $2086 \pm 166$ & $2116 \pm 138$ & $2096 \pm 190$ \\
\cline { 2 - 6 } & Post invention & $1013 \pm 62$ & $1032 \pm 34$ & $1036 \pm 54$ & $1023 \pm 42$ \\
\cline { 2 - 6 } & Decrease \%* & 53.3 & 51.4 & 52.1 & 51.4 \\
\hline
\end{tabular}

$*$ decrease $\%=$ Calories (k.cal) in pre- intervention - Calories (k.cal) in post-intervention

It was clear from data in Table (3) that the percentage of carbohydrates intake pre dietary intervention was (261\%) in group (1), followed by $(263,270 \& 268 \%)$ in groups $(2,3$ $\& 4)$ respectively. This high amount of carbohydrate intake plays an essential role in developing of obesity (James, 2008; Branca et al., 2007). After dietary intervention carbohydrate intake was (95\%) in group (1), followed by $(96,94 \& 95 \%)$ in groups $(2,3$ \& 4 ), respectively. This amount is approved with (DRIs) recommendation and help patients for loss weight without side effect. This result agreed with Feinman et al. (2015), McArdle et al. (2016), Hooper et al. (2015) and Noto et al. (2013) who reported that the amount of carbohydrate in low caloric diet is less than $130 \mathrm{~g} /$ day.

Table (3): Daily macronutrients and fibers intake (pre \& post) study for obese adult female patients compared to DRIs.

\begin{tabular}{|c|c|c|c|c|c|}
\hline $\begin{array}{l}\text { Measuring } \\
\text { parameter }\end{array}$ & Treatment & Group 1 & $\begin{array}{l}\text { Group } 2 \text { (black } \\
\text { cumin) }\end{array}$ & $\begin{array}{l}\text { Group } 3 \\
\text { (fennel) }\end{array}$ & Group 4 (mix) \\
\hline \multirow[t]{5}{*}{ Carbohydrate (g) } & DRI & 130 & 130 & 130 & 130 \\
\hline & Pre invention & $319 \pm 27$ & $322 \pm 23$ & $331 \pm 19$ & $328 \pm 24$ \\
\hline & Post invention & $124 \pm 3.9$ & $125 \pm 4.3$ & $123 \pm 5.1$ & $124 \pm 5.2$ \\
\hline & Pre invention $\%$ & 261 & 263 & 270 & 268 \\
\hline & Post invention $\%$ & 95 & 96 & 94 & 95 \\
\hline \multirow[t]{5}{*}{ Protein $(\mathrm{g})$} & DRI & 46 & 46 & 46 & 46 \\
\hline & Pre invention & $81 \pm 7.4$ & $79 \pm 6.8$ & $80 \pm 8.2$ & $82 \pm 6.3$ \\
\hline & Post invention & $57 \pm 3.7$ & $55 \pm 4.2$ & $56 \pm 3.2$ & $58 \pm 5.1$ \\
\hline & Pre invention $\%$ & 176 & 171 & 174 & 178 \\
\hline & Post invention $\%$ & 123.9 & 119.5 & 121.7 & 126.0 \\
\hline \multirow[t]{5}{*}{ Fat $(\mathrm{g})$} & DRI & 30 & 30 & 30 & 30 \\
\hline & Pre invention & $59 \pm 2.3$ & $61 \pm 3.4$ & $60 \pm 1.9$ & $59 \pm 2.6$ \\
\hline & Post invention & $29 \pm 3.6$ & $30 \pm 4.2$ & $31 \pm 5.2$ & $29 \pm 3.4$ \\
\hline & Pre invention $\%$ & 168 & 174 & 171 & 170 \\
\hline & Post invention $\%$ & 96 & 100 & 103 & 97 \\
\hline \multirow[t]{5}{*}{ Fibers $(\mathrm{g})$} & DRI & 25 & 25 & 25 & 25 \\
\hline & Pre invention & $19.2 \pm 2.8$ & $18.3 \pm 1.9$ & $17.2 \pm 3.1$ & $18.4 \pm 2.4$ \\
\hline & Post invention & $26.2 \pm 1.1$ & $26.5 \pm 1.4$ & $25.3 \pm .89$ & $26.1 \pm 1.6$ \\
\hline & Pre invention $\%$ & 76.8 & 73.2 & 68.8 & 73.6 \\
\hline & Post invention $\%$ & 104.8 & 106 & 101 & 104.4 \\
\hline
\end{tabular}

With regard of protein intake pre intervention, the results showed that percentage of protein intake was $(176 \%)$ in group (1), followed by $(171,174 \& 178$ $\%)$ for groups $(2,3 \& 4)$, respectively. Protein intake post dietary intervention for groups (1, 2, 3 \& 4) was (123.9, 119.5, $121.7 \& 126 \%)$, respectively. Protein intake has been reduced, as part of the general reduction in calories; however the rates were higher than DRIs recommendations. Other studies indicated 


\section{Effect of low caloric diet supplemented by fennel (Foeniculum vulgare) seeds or black cumin (Nigella sativa) seeds and its mixture on obese adult female patients}

that high-protein diets produce greater short-term mean weight loss as compared to standard-protein diets (Wycherley et al., 2012; Santesso et al., 2012; Clifton, 2012).

In case of fat intake percentage pre dietary intervention, results showed that fat intake was $(168 \%)$ in group (1), followed by $(174,171 \& 170 \%)$ for groups $(2,3 \&$ 4 ), respectively, the excess consumption of fat leads to its accumulation and storage in adipose tissue which causes obesity. This results agreed with Coelho et al. (2011) who found that dietary fat composition can lead to development of obesity due to the specific roles of some fatty acids that have different metabolic activities, which can alter both fat oxidation and deposition rates, resulting in changes in body weight and/or composition. After dietary intervention fat intake was (96\%) in group (1) compared to DRIs, followed by (100, $103 \& 97 \%)$ for groups $(2,3 \& 4)$, respectively.

Fibers intake by group (1) was 76.8 $\%$ from DRIs requires pre intervention, followed by $(73.2,68.8 \& 73.6)$ for groups (2, $3 \& 4)$, respectively. While, post intervention group (1) intake was (104.8 $\%)$ of fibers, followed by $(106,101 \&$ $104.4 \%)$ for groups $(2,3 \& 4)$ respectively as compared with DRIs requirements of fbers. The decrease in consumption of fiber pre dietary intervention reflex one of obesity reasons in the cases because of the importance of fibers in maintaining health body weight according to its role in decreasing levels of blood sugars and lipid, in addition to helping body in waste secretion and play a role in energy metabolism. Semih and selin (2014) reported that increasing the intake of high fiber foods or fiber supplements improves serum lipoprotein levels, lowers blood pressure, improves blood glucose levels for diabetic individuals and aids weight loss.

Data $n$ Table (4) indicated that the percentage of iron intake pre intervention was $(63.3,57.2,60$ and $62.2 \%)$ for groups $(1,2,3$ and 4), respectively, while their respective post dietary intervention was (91.1, 88.3, 91.6 and 89.4). The percentage of calcium intake pre intervention was 122.4, 136.2, 119.3 and $121.4 \%$ ) for groups (1, 2, 3 and 4), respectively, while their respective post interventions was 85.4, 92.1, 91.3 and $91.5 \%$. The percentage of phosphorus daily intake pre intervention was 112.7, 113.1, 120.1 and $111.1 \%$ in groups $(1,2,3$ and 4$)$, respectively, while it was 108, 110.2, 111.7 and $113.1 \%$ in post intervention.

Table (4). Minerals mean intake for obese adult female patients as compared to DRIs.

\begin{tabular}{|l|l|c|c|c|c|}
\hline $\begin{array}{l}\text { Measuring } \\
\text { parameter }\end{array}$ & Treatment & $\begin{array}{c}\text { Group 1 } \\
\text { control) }\end{array}$ & $\begin{array}{c}\text { Group 2 (black } \\
\text { cumin) }\end{array}$ & $\begin{array}{c}\text { Group 3 } \\
\text { (fennel) }\end{array}$ & Group 4 (mix) \\
\hline \multirow{5}{*}{ Iron (g) } & DRI & 18 & 18 & 18 & 18 \\
\cline { 2 - 6 } & Pre invention & $11.4 \pm 2.3$ & $10.3 \pm 1.9$ & $10.8 \pm 1.8$ & $11.2 \pm 1.6$ \\
\cline { 2 - 6 } & Post invention & $16.4 \pm 2.3$ & $15.9 \pm 3.5$ & $16.5 \pm 3.8$ & $16.1 \pm 2.8$ \\
\cline { 2 - 6 } & Pre invention \% & 63.3 & 57.2 & 60.0 & 62.2 \\
\cline { 2 - 6 } & Post invention \% & 91.1 & 88.3 & 91.6 & 89.4 \\
\hline \multirow{5}{*}{ Calcium (g) } & DRI & 1000 & 1000 & 1000 & 1000 \\
\cline { 2 - 6 } & Pre invention & $1224 \pm 174$ & $1362 \pm 69$ & $1193 \pm 135$ & $1214 \pm 166$ \\
\cline { 2 - 6 } & Post invention & $954 \pm 35$ & $921 \pm 52$ & $913 \pm 42$ & $915 \pm 37$ \\
\cline { 2 - 6 } & Pre invention \% & 122.4 & 136.2 & 119.3 & 121.4 \\
\cline { 2 - 6 } & Post invention \% & 95.4 & 92.1 & 91.3 & 91.5 \\
\hline \multirow{5}{*}{ Phosphors (g) } & DRI & 700 & 700 & 700 & 700 \\
\cline { 2 - 6 } & Pre invention & $789 \pm 79$ & $792 \pm 92$ & $841 \pm 85$ & $778 \pm 76$ \\
\cline { 2 - 6 } & Post invention & $756 \pm 36$ & $772 \pm 41$ & $782 \pm 23$ & $792 \pm 47$ \\
\cline { 2 - 6 } & Pre invention \% & 112.7 & 113.1 & 120.1 & 111.1 \\
\cline { 2 - 6 } & Post invention \% & 108.0 & 110.2 & 111.7 & 113.1 \\
\hline
\end{tabular}


Results in Table (5) revealed that the mean height of obesity patients was $162.3 \pm 8.5$ $(\mathrm{cm})$ in group (1), followed by (163.1 \pm 7.6 , $162.3 \pm 6.5 \& 161.7 \pm 7.5 \mathrm{~cm})$ in groups $(2,3$ $\& 4)$, respectively. Related to body weight decrease percentage, the results revealed that group (1) received low caloric diet without supplementation recorded $(5.7 \pm 1.23 \%)$ decreasing in body weight. This results agreed with Gonzalez-Campoy et al. (2013) who reported that prescription of low caloric diets containing reduction of
500-1000 kcal/day from usual intake will provide a weight loss of approximately $0.5-1 \mathrm{~kg} /$ week. The percentage of body weight loss increased to $(7.9 \pm 1.72$, $6.4 \pm 1.59 \& 7.2 \pm 1.26 \%)$ in groups $(2,3 \&$ $4)$, respectively. It was observed that black cumin seeds increased percentage of body weight loss in group (2), more than group (4) which received mix from fennel and black cumin seeds, more than group (3) which received fennel seeds.

Table (5). Anthropometric measurements for obese adult female patients after one month of dairy intervention.

\begin{tabular}{|c|c|c|c|c|c|}
\hline $\begin{array}{l}\text { Measuring } \\
\text { parameter }\end{array}$ & Treatment & $\begin{array}{c}\text { Group } 1 \\
\text { control }\end{array}$ & $\begin{array}{c}\text { Group } 2 \\
\text { Black cumin }\end{array}$ & $\begin{array}{c}\text { Group } 3 \\
\text { Fennel }\end{array}$ & $\begin{array}{l}\text { Group } 4 \\
\text { mix }\end{array}$ \\
\hline Height $(\mathrm{cm})$ & & $162.3 \pm 8.5$ & $163.1 \pm 7.6$ & $162.3 \pm 6.5$ & $161.7 \pm 7.5$ \\
\hline \multirow[t]{3}{*}{ Weight (kg) } & Pre invention & $90.8 \pm 6.4$ & $89.2 \pm 5.6$ & $88.5 \pm 5.5$ & $90.3 \pm 6.2$ \\
\hline & Post invention & $85.6 \pm 6.1$ & $82.1 \pm 5.4$ & $82.8 \pm 6.1$ & $83.8 \pm 5.8$ \\
\hline & $\downarrow \%$ & $5.7 \pm 1.23^{\mathrm{c}}$ & $7.9 \pm 1.72^{\mathrm{a}}$ & $6.4 \pm 1.39^{b}$ & $7.2 \pm 1.26^{\mathrm{ab}}$ \\
\hline \multirow[t]{3}{*}{ BMI } & Pre invention & $34.2 \pm 2.4$ & $33.5 \pm 1.6$ & $33.9 \pm 1.5$ & $34.6 \pm 3.11$ \\
\hline & Post invention & $31.9 \pm 2.29$ & $30.4 \pm 1.74$ & $31.3 \pm 2.12$ & $31.7 \pm 2.85$ \\
\hline & $\downarrow \%$ & $7.16 \pm 0.99^{\mathrm{bc}}$ & $8.65 \pm 1.20^{\mathrm{a}}$ & $7.65 \pm .96^{b}$ & $8.29 \pm 1.0^{\mathrm{ab}}$ \\
\hline \multirow[t]{3}{*}{$\mathrm{WC}(\mathrm{cm})$} & Pre invention & $111 \pm 6.74$ & $106 \pm 5.25$ & $107 \pm 4.22$ & $108 \pm 5.26$ \\
\hline & Post invention & $104 \pm 5.73$ & $98 \pm 4.47$ & $100 \pm 3.85$ & $101 \pm 4.72$ \\
\hline & $\downarrow \%$ & $6.45 \pm 1.4^{\mathrm{b}}$ & $8.21 \pm 1.3^{\mathrm{a}}$ & $7.26 \pm 1.6^{\mathrm{ab}}$ & $7.64 \pm 1.0^{\mathrm{a}}$ \\
\hline \multirow[t]{3}{*}{$\mathrm{AC}(\mathrm{cm})$} & Pre invention & $36.3 \pm 2.21$ & $34.6 \pm 2.10$ & $34.9 \pm 1.08$ & $35.4 \pm 1.71$ \\
\hline & Post invention & $33.6 \pm 1.96$ & $31.4 \pm 1.55$ & $32.1 \pm 0.97$ & $32.4 \pm 1.55$ \\
\hline & $\downarrow \%$ & $7.63 \pm .8^{b}$ & $9.24 \pm 1.3^{\mathrm{a}}$ & $8.12 \pm .85^{\mathrm{ab}}$ & $8.61 \pm .9^{\mathrm{a}}$ \\
\hline \multirow[t]{3}{*}{ TSF (mm) } & Pre invention & $35.2 \pm 1.01$ & $33.3 \pm 1.45$ & $34.2 \pm 1.27$ & $35.5 \pm 1.62$ \\
\hline & Post invention & $31.9 \pm 1.09$ & $27.8 \pm 1.37$ & $30.1 \pm 1.10$ & $30.9 \pm 1.58$ \\
\hline & $\downarrow \%$ & $9.6 \pm 1.7^{\mathrm{c}}$ & $15.5 \pm 2.2^{\mathrm{a}}$ & $11.9 \pm 1.8^{\mathrm{b}}$ & $12.7 \pm 0.8^{b}$ \\
\hline \multirow[t]{3}{*}{$\mathrm{AMC}(\mathrm{cm})$} & Pre invention & $25.3 \pm 2.1$ & $24.1 \pm 1.8$ & $23.2 \pm 1.6$ & $24.3 \pm 2.3$ \\
\hline & Post invention & $23.6 \pm 1.4$ & $22.7 \pm 2.1$ & $21.6 \pm 1.8$ & $22.8 \pm 1.7$ \\
\hline & $\downarrow \%$ & $6.7 \pm .72^{b}$ & $5.8 \pm .54^{\mathrm{a}}$ & $6.6 \pm .43^{b}$ & $6.2 \pm .81^{b}$ \\
\hline
\end{tabular}

With regard of body mass index (BMI), results in Table (5) showed that its value in group (1) was $(7.16 \pm 0.99$, $8.65 \pm 1.20,7.65 \pm 1.23 \& 8.29 \pm 1.26 \%$ ) for groups $(1,2,3 \& 4)$, respectively. The significant decrease in BMI was $(8.65 \pm 1.20 \%)$ in cases of group (2) which supplemented with black cumin seeds compared to group (1). Also, low caloric diet supplemented with fennel seeds in group (3) leads to insignificantly decrease of BMI in obesity female patients compared to group (1). Meanwhile, group (4) recorded significant decrease.

The percentage decrease of Waist Circumference (WC) of groups (1) was $(6.45 \pm 1.91 \%)$. Group (2) recorded significantly percentage decrease of WC $(8.21 \pm 1.30 \%)$ when compared to group (1). On the other hand, insignificant WC percentage decrease $(7.26 \pm 2.66 \quad \&$ $7.64 \pm 1.04 \%)$ was recorded in groups (3 


\section{Effect of low caloric diet supplemented by fennel (Foeniculum vulgare) seeds or black cumin (Nigella sativa) seeds and its mixture on obese adult female patients}

\& 4), respectively when compared to group (1).

Results of Arm Circumference (AC) (Table 5) indicated that the percentage of decreasing values were $(7.63 \pm .8,9.24 \pm 1.3,8.12 \pm .85 \& 8.61 \pm .9 \%)$ for groups $(1,2,3 \& 4)$, respectively. The significant AC percentage decrease $(9.24 \pm 1.3 \%)$ was in group (2) (black cumin) compared to group (1), followed by groups (4). This result indicates the effect of black cumin seeds and the mix seeds in reducing body weight.

As shown in Table (5), the decreasing percentage of TSF of group (1) was $(9.6 \pm 1.7 \%)$, while it was $(15.5 \pm 2.2$, $11.9 \pm 1.8 \& 12.7 \pm 0.8 \%)$ in groups $(2,3 \&$ $4)$, respectively compared to group (1). This is evidence that the process of burning fat was done correctly by burning fat instead of losing muscle mass.

According to $\mathrm{AMC}$, the percentage of decreasing value in group (1) was $6.7 \pm .72 \%$, while it was $5.8 \pm .54 \%$ in group (2) compared to group (1). On the other hand this was $6.6 \pm .43 \& 6.2 \pm .81 \%$ in groups ( $3 \& 4)$, respectively (insignificant decrease) compared to group (1). This result indicated that the process of burning fat was done correctly by burning fat instead of losing muscle mass.

Previous results indicated that the best weight reduction including (weight, BMI, WC, AC, TSF and AMC) was in group (2) which received black cumin seeds, followed by group (4) which received mix from (black cumin seeds and fennel seeds), followed by group (3) which received fennel seeds, followed by group (1) without supplemented seeds. This explains that black cumin seeds and fennel seeds had weight reduction effect, while black cumin seeds had the best effect. These results agreed with Aftab et al. (2013) and Vanamala et al. (2012) who reported that Nigella sativa seeds and its active substance thymoquinone showed anti-obesity effect, positive effect against cardiovascular disease and insulin sensitivity effects. Also, Datau et al. (2010) found that when obese men were given three g/day black cumin seeds powder for 3 months, a significant decrease was observed in their body weight, and waist and hip circumference. Also, Fararh et al. (2010) demonstrated significant decreasing in body weight of diabetic rats treated with $300 \mathrm{mg} /$ day black cumin extract for 30 days. On the other hand, Nawal et al. (2019) found that fennel causes weight reduction effect on obese male rats. Eman et al. (2011) reported that treatment hyperlipidemic rats with fennel enhanced their biochemical parameters.

Data in Table (6) showed that percentage of serum triglyceride was decreased in group (1) $(12.11 \pm 0.9 \%)$. This percentage increased significantly in group 2 to $(17.05 \pm 1.4 \%)$, followed by $(15.12 \pm 1.3 \& 16.10 \pm 2.1 \%)$ in groups $(3 \&$ $4)$, respectively.

The highest percentage for cholesterol levels changes was $16.09 \pm 2.7$ $\%$ in group (2), followed by. group (4) (14.92 \pm 2.4$)$, group (3) $(13.98 \pm 3.3)$ and group (1) (11.93 \pm 1.5$)$.

LDL decreasing percentage was $(12.12 \pm 1.2 \%)$ in group (1), $(16.05 \pm 1.9 \%)$ in group (2), followed by $(14.04 \pm 2.1 \&$ $14.92 \pm 1.8 \%$ ) in groups (3 and 4), respectively. This indicates that best results had been obtained in group (2).

HDL percentage was $(15.79 \pm 4.5$, $13.89 \pm 3.0 \& 14.71 \pm 2.9 \%)$ in groups $(2,3$ $\& 4)$, respectively, recorded significant increasing results compared to group (1) $(10.25 \pm 2.1 \%)$. The best result was obtained in group (2) which supplemented with black cumin.

According to this results low caloric diet play an important role in decreasing the excessive of blood lipids (cholesterol, triglyceride and LDL), while increased the percentage of HDL (good cholesterol). The supplementation with fennel seeds, black cumin seeds and its mixture with low caloric diet decreased cholesterol, triglyceride and LDL levels 
Mohamed A. AbdElwahab et al.

compared to supplemented group (1), while increased HDL level compared to group (1). These results agree with Gholam et al. (2019) who reported that the levels of TG, total cholesterol, LDL, ALT, and Alkaline phosphatase significantly reduced by treatment with fennel seeds extract and the level of HDL significantly increased. Previous study of Moeen-ud-din et al. (2014) showed that the intake of two teaspoons of black cumin seeds for six Table (6). Effect of fennel, black cumin and its mixture on tri-glyceride, cholesterol, LDL and HDL levels of obese female patients.

\begin{tabular}{|l|l|c|c|c|c|}
\hline $\begin{array}{l}\text { Measuring } \\
\text { parameter }\end{array}$ & Treatment & $\begin{array}{c}\text { Group 1 } \\
\text { control }\end{array}$ & $\begin{array}{c}\text { Group 2 } \\
\text { Black cumin }\end{array}$ & $\begin{array}{c}\text { Group 3 } \\
\text { Fennel }\end{array}$ & $\begin{array}{c}\text { Group 4 } \\
\text { mix }\end{array}$ \\
\hline $\begin{array}{l}\text { Tri-glyceride } \\
(\mathrm{mg} / \mathrm{dl})\end{array}$ & Pre intervention & $198 \pm 14.63$ & $191 \pm 12.92$ & $194 \pm 12.90$ & $206 \pm 18.90$ \\
\cline { 2 - 6 } & Post intervention & $174 \pm 12.66$ & $158 \pm 10.67$ & $166 \pm 10.88$ & $172 \pm 15.64$ \\
\cline { 2 - 6 } & $\downarrow \%$ & $12.11 \pm 0.9^{\mathrm{c}}$ & $17.05 \pm 1.4^{\mathrm{a}}$ & $15.12 \pm 1.3^{\mathrm{b}}$ & $16.10 \pm 2.1^{\mathrm{ab}}$ \\
\hline \multirow{2}{*}{$\begin{array}{l}\text { Cholesterol } \\
(\mathrm{mg} / \mathrm{dl})\end{array}$} & Pre intervention & $235 \pm 16.97$ & $229 \pm 17.50$ & $231 \pm 14.60$ & $237 \pm 18.37$ \\
\cline { 2 - 6 } & Post intervention & $207 \pm 16.25$ & $192 \pm 16.56$ & $201 \pm 24.96$ & $203 \pm 17.38$ \\
\cline { 2 - 6 } & $\downarrow \%$ & $11.93 \pm 2.5^{\mathrm{cb}}$ & $16.09 \pm 2.7^{\mathrm{a}}$ & $13.98 \pm 3.3^{\mathrm{b}}$ & $14.92 \pm 2.4^{\mathrm{ab}}$ \\
\hline \multirow{2}{*}{ LDL (mg/dl) } & Pre intervention & $173 \pm 7.92$ & $169 \pm 8.37$ & $169 \pm 7.62$ & $179 \pm 8.31$ \\
\cline { 2 - 6 } & Post intervention & $152 \pm 7.73$ & $142 \pm 6.67$ & $145 \pm 6.73$ & $153 \pm 7.21$ \\
\cline { 2 - 6 } & $\downarrow \%$ & $12.12 \pm 1.2^{\mathrm{b}}$ & $16.05 \pm 1.9^{\mathrm{a}}$ & $14.04 \pm 2.1^{\mathrm{a}}$ & $14.92 \pm 1.8^{\mathrm{a}}$ \\
\hline \multirow{2}{*}{ HDL (mg/dl) } & Pre intervention & $39 \pm 2.64$ & $39 \pm 2.72$ & $37 \pm 2.83$ & $38 \pm 2.91$ \\
\cline { 2 - 6 } & Post intervention & $43 \pm 3.22$ & $45 \pm 2.12$ & $42 \pm 2.84$ & $45 \pm 3.09$ \\
\cline { 2 - 7 } & $\uparrow \%$ & $10.25 \pm 2.1^{\mathrm{b}}$ & $15.79 \pm 2.5^{\mathrm{a}}$ & $13.89 \pm 2.0^{\mathrm{a}}$ & $14.71 \pm 2.9^{\mathrm{a}}$ \\
\hline
\end{tabular}

The increase percentage of hemoglobin level in group (1) was $(9.85 \pm 2.55 \%)$, while it increased to $(11.11 \pm 3.24,9.92 \pm 2.70 \& 10.16 \pm 4.64 \%)$ weeks by hyperlipidemic patients decreased their LDL-C and increased their HDL-C. Also, Mahdieh et al. (2018) reported that treatment with black cumin reduced body weight and body mass index (BMI). Serum concentrations of LDL and TG also decreased in black cumin treated group after 8 weeks, while serum HDL significantly increased after treatment with black cumin seeds. in groups (2, $3 \& 4)$, respectively. The increasing in hemoglobin levels in all groups may related to increasing iron intake post dietary intervention.

Table (7). Effect of fennel, black cumin and its mixture on Hemoglobin level of obese female patients.

\begin{tabular}{|l|c|c|c|c|}
\hline $\begin{array}{l}\text { Hemoglobin } \\
(\mathrm{g} / \mathrm{dl})\end{array}$ & $\begin{array}{c}\text { Group 1 } \\
\text { control }\end{array}$ & $\begin{array}{c}\text { Group 2 } \\
\text { Black cumin }\end{array}$ & $\begin{array}{c}\text { Group 3 } \\
\text { Fennel }\end{array}$ & $\begin{array}{c}\text { Group 4 } \\
\text { mix }\end{array}$ \\
\hline Pre intervention & $\begin{array}{c}198 \pm 12.7 \pm 1.73 \\
14.63\end{array}$ & $13.2 \pm 2.82$ & $13.2 \pm 1.95$ & $12.9 \pm 1.69$ \\
\hline Post intervention & $13.9 \pm 1.80$ & $14.8 \pm 2.44$ & $14.6 \pm 1.55$ & $14.5 \pm 1.54$ \\
\hline$\%$ & $9.85 \pm 1.55^{\mathrm{a}}$ & $11.11 \pm 1.24^{\mathrm{a}}$ & $9.92 \pm 1.70^{\mathrm{a}}$ & $10.16 \pm 1.64^{\mathrm{a}}$ \\
\hline
\end{tabular}

\section{Conclusion:}

Low caloric diet help to reduce body mass index (BMI) and improve lipid profile, while low caloric diet

supplemented with black cumin seeds decreasing significantly the rate of BMI as well as improving lipid profile while fennel seeds improved insignificantly lipid profile and decreasing BMI. 

cumin (Nigella sativa) seeds and its mixture on obese adult female patients

\section{REFERENCES}

Abd-Elkader, M. (2001). Assessment of nutritional status. Arab Nile GroupCairo- Egypt., 1: 51-83.

American Dietetic Association (ADA) (2008). Practice for dietetic technicians, registered in nutrition care and standards of professional performance for dietetic technicians registered. Published by Elsevier Inc. DOI:https://doi.org/10.1016/j.jada. 2008.07.001

Aftab, A.; Asif, H.; Mohd, M.; Shah, A.; Abul, K.; Nasser, A.; Zoheir, A. and Firoz, A. (2013). A review on therapeutic potential of Nigella sativa: A miracle herb. Asian Pacific J. Trop. Biomed., 3: 337352.

Clifton, P. (2012). Effects of a high protein diet on body weight and comorbidities associated with obesity. Brit. J. Nutr., 108: 122129.

Coelho, D.; Pereira-Lancha, L.; Chaves, D.; Diwan, D.; Ferraz, R.P.L.; Campos-Ferraz, J. and Lancha, A. (2011). Effect of high-fat diets on body composition, lipid metabolism and insulin sensitivity, and the role of exercise on these parameters. Braz. J. Med. Biol. Res., 44: 966-972.

Datau, E.W.; Surachmanto, E.; Pandelaki, K. and Langi J. (2010): Efficacy of Nigella sativa on serum free testosterone and metabolic disturbances in central obese male. Acta Med. Indones., 42: 130-134.

Dudek, S. (2001). Nutrition essentials for nursing practice, Philadelphia, Lippincott, new york., 4: 173, 412413. .

Eman, G.; Fatma, A. and Amira, M. (2011). Effect of fennel (Foeniculum vulgare) on hyperlipidemic rats. Egypt. J. Hospital Med., 43: 212 - 225.
Fararh, K.; Ibrahim, A. and Elsonosy Y. (2010). Thymoquinone enhances the activities of enzymes related to energy metabolism in peripheral leukocytes of diabetic rats. Res. Veter. Sci., 88: 400-404.

Feinman, R.; Pogzelski, W.; Astrup, A.; Bernstein, R.; Fine, E. and Westman, E. (2015). Dietary carbohydrate restriction as the first approach in diabetes management: critical review and evidence base. Nutr., 31: 1-13.

Gholam, A.; Mehrdad, R.; Elham, E.; Elham, Z. and Ashkan, S. (2019). The effect of Foeniculum vulgare (Fennel) hydroalcoholic extract on serum lipid profiles and liver enzymes in male rats fed a high cholesterol regimen. J. Basic and Clin. Pathophysiol., 7(2):20-27.

Gonzalez-Campoy, J.; St-Jeor, S.; Castorino, K.; Ebrahim, A.; Hurley, D. and Jovanovic, L. (2013). Clinical practice guidelines for healthy eating for the prevention and treatment of metabolic and endocrine diseases in adults: cosponsored by the American Association of Clinical Endocrinologists/the American College of Endocrinology and the Obesity Society. Endocrine Practice, 19: 1-82.

Hasani-Ranjbar, S.; Jouyandeh, Z. and Abdollahi, M. (2013): A systematic review of antiobesity medicinal plants-an update. J. Diabetes Metabolic Disorders, 12: 28.

Heping, Z.; C.J.Urso and Viren, J. (2020): Saturated fatty acids in obesityassociated inflammation. J. Inflamm. Res., 13: 1-14.

Heshmati J. and Namazi N. (2015): Effects of black seed (Nigella sativa) on metabolic parameters in diabetes mellitus: A systematic review. Complementary Therapies in Medicine., 23: 275-282. 
Mohamed A. AbdElwahab et al.

Hooper, L.; Abdelhamid, A.; Bunn, D.; Brown, T.; Summerbell, C. and Skeaff, C. (2015). Effects of total fat intake on body weight. The Cochrane Database of Systematic Reviews, (8): CD011834.

James, W. (2008). The Epidemiology of obesity: The size of the problem. J. Int. Med., 263: 336-52.

Branca, F.; Nikogosian, H. and Lobstein, T. (2007). The challenge of obesity in the WHO European region and the strategies for response: Summary. Copenhagen: WHO Regional Office for Europe.

Mahdieh, A.; Parvin, D. and Siroos, T. (2018). Powdered black cumin seeds strongly improves serum lipids, antherogenic index of plasma and modulates anthropometric features in patients with Hashimoto's thyroiditis. Lipids in Health and Disease, 17:5.

McArdle, P.; Mellor, D.; Rilstone, S. and Taplin, J. (2016). The role of carbohydrate in diabetes management. Practical Diabetes, 33: 237-242.

Moeen-ud-din, H.; Murad, S. and Fatima, A. (2014). Placebo controlled study on comparison of effects of Nigella sativa and nicotinic acid along with low fat diet and physical exercise on LDL-cholesterol and HDLcholesterol. Pak. J. Med. Health Sci., 8:306-9.

Nawal, A.; Eman, H.; Hala, H.; Mohamed, M. and Nour, El din, A. (2019). Beneficial effects of fennel (Foeniculum vulgare) in treating obesity in rats. J. Obesity Manag., 1:1-16.

Nazma, A.; Nazmul, K. and Hossain, S. (2017). Obesity: A review of pathogenesis and management strategies in adult. Delta Med. Col. J., 5:35-48.

Nhlbi, N. (1998). Expert Panel on the Identification Evaluation and Treatment of Overweight and
Obesity in Adults. Clinical Guidelines on the Identification, Evaluation, and Treatment of Overweight and Obesity in Adults - The Evidence Report. National Institutes of Health Obes. Res., 6: 51S-209S.

Noto, H.; Goto, A.; Tsujimoto, T. and Noda, M. (2013). Low carbohydrate diets and all-cause mortality: a systematic review and metaanalysis of observational studies. PLoS One, 8(1): E55030.

Polikandrioti, M. and Stefanou, E. (2009). Obesity disease. Health Sci. J., 3: 132-138.

Santesso, N.; Akl, E.A.; Bianchi, M.; Mente, A.; Mustafa, R. and HeelsAnsdell, D. (2012). Effects of higher- versus lower-protein diets on health outcomes: a systematic review and meta-analysis. Eur. J. Clin. Nutr., 66: 780-788.

Semih, O. and Selin, O. (2014). Health effects of dietary fiber. Acta Sci. Pol., Technol. Aliment., 13: 191202.

Shahid, A. (2018). Fennel (Foeniculum vulgare Mill.): A Common Spice with Unique Medicinal Properties. Annals of Complementary and Alternative Medicine., 1(1):1001.

Vanamala, J.; Kester, A.; Heuberger, A.L. and Reddivari, L. (2012). Mitigation of obesity promoted diseases by Nigella sativa and thymoquinone. Plant Foods for Human Nutr.., 67: 111-119.

Wendy, M.; Katherine, E.; Martin, L.; Jose, Y. and Peter, A. (2005). Obesity and lipids. Current Cardiology Reports., 7: 465-470.

Wycherley, T.; Moran, L.; Clifton, P.; Noakes, M. and Brinkworth, G. (2012). Effects of energy-restricted high-protein, low-fat compared with standard-protein, low-fat diets: a meta-analysis of randomized controlled trials. Am. J. Clin. Nutr., 96: 1281-1298. 
Effect of low caloric diet supplemented by fennel (Foeniculum vulgare) seeds or black cumin (Nigella sativa) seeds and its mixture on obese adult female patients

تاثير النظام الغذائي قليل السعرات المدعم ببذور الثمر و بذورالكمون الاسود وخليطهما عليمريضات السمنة البالغات

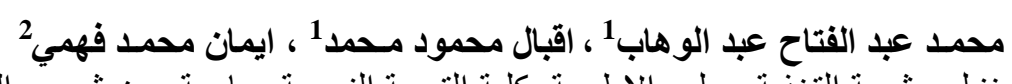

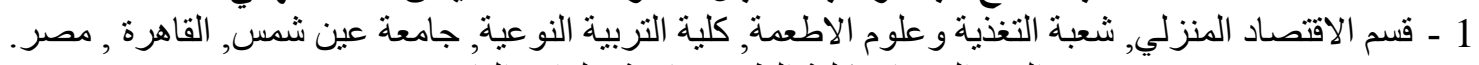



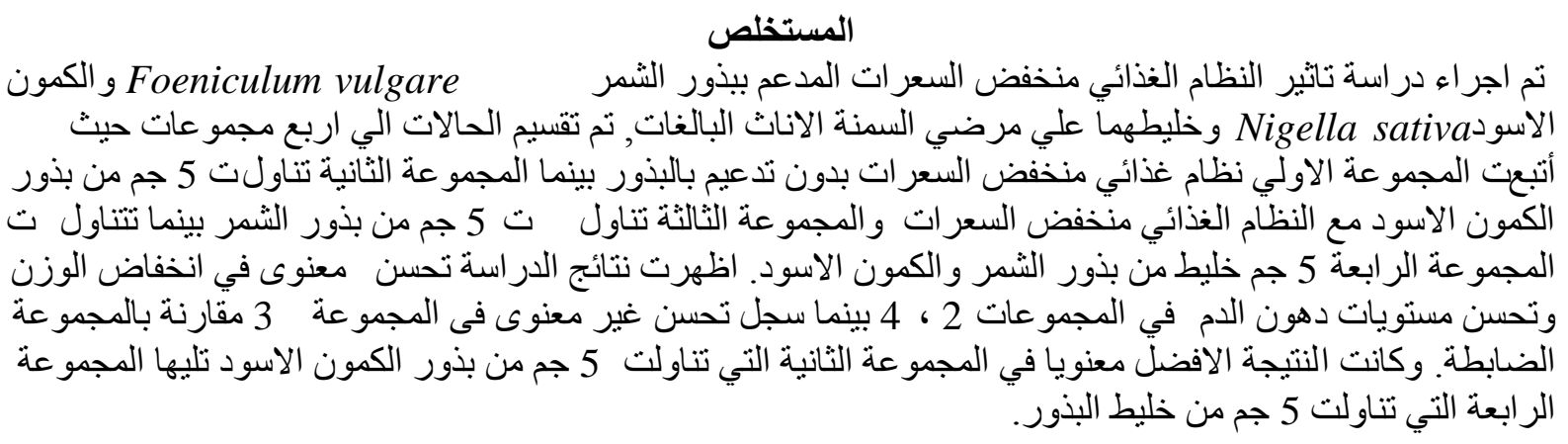

